\title{
Austerity and Governance: Coordinating Policing and Mental Health Policy in the UK
}

\author{
Pre-publication version
}

$\underline{\text { To cite this article: }}$

Carlos Solar \& Martin Smith (2020) Austerity and governance: coordinating policing and mental health policy in the UK, Policy Studies, online first,

DOI: https://doi.org/10.1080/01442872.2020.1711876 


\title{
Austerity and Governance: Coordinating Policing and Mental Health Policy in the UK
}

\begin{abstract}
Notions of network and polycentric governance highlight the possibility of innovation and adaptability in service delivery. At the same time, it has been argued that austerity and financial restrictions create strong pressures for public sector reform as public sector organisations look to new ways to deliver services. Hence the argument from governments in advanced democracies was that austerity would drive innovation. This article argues, through an analysis of the issue of policing and mental health in the UK, that network governance and polycentrism can be a major constraint on reform when policy is delivered through multiple overlapping agencies, but with a lack of overarching authority. In the case of policing and mental health, introducing new governance arrangements is complex, much more so in a context of austerity. Resistance within organizations can oppose to novel forms of governance and the new demands created by expenditure cuts further stress service delivery.
\end{abstract}

Keywords: Network governance, polycentrism, policing, public policy, mental health and England

\section{Introduction}

Before the economic and financial crisis of 2008, governments used the relatively lax international credit regime to fund substantial expansion in welfare spending. For the advanced democracies, this period was in many ways a golden age with significant increase of spending, particularly in health and education (Smith 2014). Nevertheless, the subsequent economic crisis has resulted in a policy of austerity being adopted in many countries from the group of advanced democracies (Blyth 2013). In the UK there has been a conscious effort to reduce and reconfigure the size and functions of the state guided by the belief that financial necessity will drive reform in the provision of public services. The assumption has been that changes in forms of service delivery mean that new forms of governance can produce better quality services with reduced costs (see Curristine, Lonti and Joumard 2007). There is considerable pressure to end policy silos and improve service delivery happening through networks and partnerships of a range 
of public and private agencies. As the management consultants PricewaterhouseCoopers (2007) suggested over a decade ago:

In different organisations, key factors involved in the drive to build connected government will include building visible leadership at a strategic level, setting common goals (service standards) for connected government, focusing on the front end (where services are actually delivered), breaking down inter-agency silos before moving to dismantle interagency silos and putting in place an enabling and legal framework.

In other words, what Ostrom (2010) calls polycentric governance is seen as a mechanism for decentralising governance in order to create negotiated solutions through nested interactions. However, this article demonstrates that the sort of ad hoc changes in policy delivery expected by austerity and the governance literature are difficult to make within the existing polycentric institutional and political arrangements. The article examines certain challenges to our understanding of existing modes of governing in the UK. On the one hand, despite the long-term fragmentation of service delivery, there is an over-emphasis on the degree of the ability of the centre to control services at the local level. What the article illustrates is that the potential for decentralised policy implementation is considerable. On the other hand, new forms of polycentric governance do not produce the forms of flexibility that the literature assumes. Indeed, fragmentation and local level decision-making complexify reform processes because no single actor is in control of the policy process and hence lacks the authority to implement reforms which depend on multi-agency cooperation.

Through a detailed and in-depth case study of policing and mental health we demonstrate that there is a residual conflict between the strong desire for reform and the embedded polycentric institutional arrangements which make reform under austerity difficult. The article reveals that whilst in terms of how services are organized, we have seen the development of network governance. However, there has not been similar institutional adaptation. Consequently, the forms of governance are increasingly out of sync with the patterns of institutional arrangement. In particular, the inability or unwillingness of public sector organizations to rethink budgeting (particularly in the context of cuts) makes radical realignment of service delivery difficult. The article begins by outlining the macro-political situation in the UK, it moves on to examine a 
model of decentralisation, and then studies the empirical evidence of local governance responses to austerity by looking at the management of policing and mental health in the northern region of North Yorkshire. The article derives from extensive field work research where the authors were able to access first-hand accounts of policing and mental health policy initiatives taking place in major metropolitan areas, including, Manchester, Birmingham, and Leeds-Bradford. The article evaluates the key public policy sectors of policing and health in order to influence cross-national debates under the broader conceptual issues of policymaking, austerity, and governance. As well, we aim to expand our knowledge on policy processes implemented through regional governance projects in the advanced and developing countries (see, for example, Lidén, Nyhlén, and Nyhlén 2015; Liu, Li, Xi, and Koppenjan, 2016; Dare and Daniell 2017).

\section{Austerity, governance and the realignment of public services}

In the UK, public expenditure has been reduced from 44 percent of GDP in 2010 to 40 per cent in 2015 and cuts have not been distributed equally (IFS 2015). Some departments, such as the Home Office, have seen very large reductions in spending. Certain services, in particular local government and the police, have seen much more significant cuts with around 20 per cent for the police and about 27 per cent for local government by 2019 (Local Government Association 2013). Yet the argument that has been developed within the government is that public services can adapt to the challenges of resource constraints by being much more effective and efficient in how they provide services.

Reform of the public services under the Coalition between 2010 and 2015 and later in the Conservative administration is based on an idea that market pressures create innovations that produce more effective service delivery. There is a presumption in the government's approach to austerity that budget cuts will drive change and produce better outcomes. This view is supported by a belief that in many cases satisfaction with public services does not seem to have declined since the fiscal crisis (see OECD 2013). This view matches with much of the academic governance literature which going back to Osborne and Gaebler (1994) sees network government as developing a flexibility and plurality of governance approaches (see also, Crosby and Bryson 2010; Isett et al. 2011; Bevir 2011). 
This economistic model of public sector reform sees necessity as the mother of intervention. Economic constraint is the catalyst of public sector reform. The austerity model of public sector reform is based on the idea that resource constraint does two things. One, it reduces demand as individuals take increasing responsibility for their own actions (as in Universal Credit and benefits reforms), or they turn to the voluntary sector (as is the case of food banks). Second, economic pressures produce institutional reforms -so for example cuts in police numbers will improve the efficiency of back office functions that minimise the impact on front-line service delivery.

Hence what government advocated is what can be seen as an extension of the type of network governance that has been developing since the 1980s with the reform of the public services. Austerity, on the other hand, is layered upon this long period of public sector reform. Network governance focuses on the way in which the delivery of services no longer occurs through a bureaucratic hierarchy but through often complex relationships between a range of agencies (in the public, private and voluntary sectors) who work together to deliver their goals. As Provan and Kenis (2008) point out, networks can either be participatory in which relationships between partners are relatively equal and no institution is in an authoritative position or lead organization networks where one single agency coordinates activities. Gerry Stoker $(2011,7)$ noted:

Networked community governance frames issues by recognizing the complex architecture of government. In practice there are many centres and diverse links between many agencies of government at neighbourhood, local, regional and national and supranational levels. In turn each level has a diverse range of horizontal relationships with other government agencies, privatized utilities, private companies, voluntary organizations and interest groups. The model retains a strong role for local government as a coordinator in order to join up and steer a complex set of processes.

However, in the case of policing and mental health the network is more of a participatory and polycentric model with no overall coordinator. The peculiarities of the British system are that central government can be a significant influence through its near monopoly of financing and policy making. Yet, at the same time it has limited control over local administration. The resulting networks operate within the context of a framework very much set by the centre. Notions of polycentrism and network 
governance model therefore ignore three variables. One is the complexity of introducing new governance arrangements and the extent to which existing institutional forms have been created in relation to specific functionality. The problem is that whilst the network may have a flat structure; the organizations that make up the participants are usually hierarchical. For instance, both the police and the National Health Service (NHS) are highly bureaucratic and hierarchical organizations. The second factor is the political resistance within organizations to radical change and the unintended consequences of, and new demands created by, expenditure cuts. For example, cuts in the provision in one service may not have a dramatic effect if demand is simply shifted to another service, or the improvement in service delivery and outcomes may create more demand.

Network governance is one model used to analyse the allocation of state resources and for exercising control and co-ordination. Network governance grew in importance as societal issues demanded for "multijurisdictional" and "hybrid" patterns of governance practices that combined "people and institutions across different policy sectors and different levels of government (local, regional, national and international)" (Bevir 2011, 2). Networked governance highlights how the informal authority of networks supplements and supplants the formal authority of government (see Rhodes 2012). But whilst Ostrom (2010) sees this leading to negotiated solutions that resolve collective action problems, our argument in the case of mental health is that the lack of an overarching authority leads to sub-optimal outcomes. For example, Matthews (2012) suggested that changes implemented by advanced states resulted in a range of unintended consequences such as the emergence of new and multiple veto points at the centre of government; or the idea of polycentric governance which McGinnis and Ostrom $(2011,9)$ see as a complex combination of multiple levels and diverse types of organizations drawn from the public, private, and voluntary sectors that have overlapping realms of responsibility and functional capacities.

The third variable that we explore is that network governance and other forms of collaborative governance found in the literature result overly optimistic. We believe that inter-agency governance fails to succeed in various items involving the inclusion of actors, transparency and sharing of information, and democratic engagement. As Emerson and Nabatchi argued, "although cross-sector collaboration is increasingly believed to be necessary and desirable, it is rarely easy" $(2015,209)$. To the authors, networked and collaborative dynamics require too many essential drivers to pull off 
that are of multidimensional, dynamic and complex nature $(2015,212)$. Controlling for all of these is a great task for any organization. Network governance is compromised when individual and organizational relationships demand to great of an effort to have meaningful outcomes to any of the involved institutions (Davies 2011).

\section{Policymaking, policing and mental health}

The case of policing and mental health highlights the problems of sustaining new forms of network governance and suggests that the shift to partnership and connected government is more difficult than theorists and policy makers believe. In the case of mental health services agencies have explicit commitments to improving the quality of services but they do not always control the outputs that derive from the overall policy framework. The control of street level bureaucrats over the shape of policy at the local level exacerbates the difficulties of developing innovative forms of practice (Lipsky 1980; Hupe and Buffat 2014). The new direction of travel for policy on policing, mental health, vulnerability, has come hand-in-hand with central steering efforts to respond, among other issues, to crises and subsequent independent inquiries. For instance, through Lord Adebowale's report describing "mental health as a core police business", and the move towards "blue-light integration" of emergency services, government has restructured public sector around cost control, privatization, localism, and joined-up government (see Adebowale 2013; HM Government 2011).

In this vein, police forces have seen significant cuts in the number of officers carrying out front line duties. Of course, the problem for the police is that unlike most other services they are rarely in a position when they cannot respond to a request for help. The consequence of this is that not only are they faced with their own constraints on resources but where other services are cut (for example 24-hour crisis care), then people with a range of problems call on the police. The police are faced with increasing demands at a time of reduced resources. Police come into contact with people in mental distress as offenders, suspects, witnesses, victims, and people in suffering. It is estimated that police interventions involving individuals with mental health illness can use up to $87 \%$ more resources than interventions involving non-persons with mental health illness (Charette, Crocker and Billette 2014). This increasing demand as a result of austerity is, however, layered on top of a longer-term trend for the deinstitutionalisation of mental health which means mental health issues are 
increasingly dealt within the community. Police officers have frequently found themselves in situations where they, without proper training, are making judgments about whether people receive medical treatment or enter the criminal justice system (see Lamb, Weinberger and Walter 2002). In light of the increasing level of mental health crisis in the public, it is assumed that "the collaboration between mental health service providers and the police has become critical" (Normore, Ellis, and Bone 2015, 2). Therefore, there are strong pressures both in terms of changes in the treatment of mental illness and cuts in service provision to change the way that police approach mental illness and develop a collaborative approach. Police are spending considerable time on mental illness firstly because of increased demand but secondly because when the police are dealing with issues of mental illness in ways that exacerbate rather than resolve the problem; hence producing a situation where people with mental health issues continually return to police attention. As a consequence, demand is very difficult to control.

There is a strong requirement of interagency working as a way of better managing mental health incidents and ensure that people who need help receive treatment rather than being processed through the criminal justice system or left to their own devices. However, as the article demonstrates whilst there is a strong rhetorical commitment to interagency working, and a number of examples of good interagency practice, the reality is that institutional constraints, or more particularly an institutional misalignment, provide a strong restraint on the austerity pressure for innovative forms of interagency working. The rest of the article highlights the difficulty in using economic pressures as a mechanism for reforming public services.

\section{Methodology}

In order to examine the empirical evidence of the austerity measures in local governance we looked at the management of policing and mental health from a perspective of North Yorkshire Police. The research is part of a larger inter-disciplinary project looking at the reform of policing practices and that includes the delivery of training and an academic review of organizational practices. Even though North Yorkshire is divided into different local authorities and public services are scattered across its topography, the police force is a unitary institution that sits at the centre of a network of institutions facing common challenges of interagency governance with the 
wide spectrum of services being delivered in the region. In their role of central nod for such a network formation, the police turned into a security knowledge broker, acting as advisors and manager of law and order practices for the other institutions involved (Ericson 1994; Fleming and Rhodes 2018).

In order to take consideration of this broad range of services and their relations with the police force, we aimed to conduct unstructured interviews with decisionmakers from the most representative policy sectors. Participants $(\mathrm{N}=46)$ were selected regarding their role in the delivery of both policing and other mental health public services (i.e. police force, NHS, local governments, users, organised civil society, private organizations, charities, among others), and through field visits to other Police Forces in England (i.e. Greater Manchester, West Yorkshire, Northumbria, Leicestershire, Nottinghamshire, Norfolk, Hampshire, among others) from 2015 to 2017. The audio recorded interviews lasted between 30 minutes to one hour. We also conducted research acting as observing participants in public and private work meetings where policymakers from different fields gathered to discuss the provision of best practices for mental health and policing. In order to complement their stories, we crosschecked with governments documents, independent reports, and regional public services reports.

Our field work research aimed to illuminate on a subset of research questions that dealt with issues of network governance, professionalism, and service delivery. More specifically, we asked our participants to reflect on the constraints imposed by the context of austerity and how particular public services deal through interconnected ways with problems that they see as their core competence. Through this research strategy we sought to illuminate three puzzling ideas on how the issue of policing and mental health governance has come to frame an important trend which is likely to reflect on ongoing governance and policy at the national level. First, we investigate the introduction of new governance arrangements in a context of austerity. Second, the reaction of public service organizations to novel forms of network governance; and, third, the unintended consequences and new demands created by expenditure cuts on local service delivery.

\section{Decentralisation, austerity and network governance}


First obstacle: Introducing new governance arrangements is complex, much more so in a context of austerity

When the Coalition government introduced the Mental Health Crisis Care Concordat, policing institutions across the UK were required to abide by a new set of policy rules. However, the current model of decentralisation in the context of austerity suggests that it was more difficult than policy makers expected. When thinking about introducing new governance arrangements, two factors need to be taken into consideration: first, the degree of autonomy and decentralisation that reigned previously, and second, the disappearance of incentives (mostly budgetary) as a consequence of austerity.

The Concordat was introduced as a framework for networked governance. It was informative regarding policy reform, but lacked detail in terms of specifying how policy was to be implemented. The Home Office, sticking to its hands-off, decentralised approach, relied on the regional authorities to execute the strategy encouraging them to agree on their own priorities and processes to assess to mental health crises. The Concordat was so extensive that it made it difficult for autonomous regional actors to deliver actions expected by the centre (Smith, Richard, Geddes, and Mathers 2011). The Concordat's chapter for North Yorkshire and York was organized as a tier structure composed of five different levels where a multitude of public services were represented, including those in policing and mental health. It aimed to promote collaborative and inter-agency responses from the institutions involved. Guidelines for policy were to be steered from top to bottom, however, consensus and co-ordination for policy delivery remained a matter belonging to the horizontal relationships created in each tier. The overall structure favoured increased deliberation in the decision-making but the institutional complexity of trying to arrange network governance became an obstacle to policy implementation. Local actors struggled to overcome receding and constrained budgets, organizational remits, hierarchical and layered bureaucracies, and their different interests and expected benefits from partaking in such governing engagements. Such obstacles to network governance have been further undermined by a lack of steering dynamics to stimulate policy cooperation. Effectiveness depended, not on set institutional arrangements but on the trust through informal personal relationships. In other words, the new forms of delivery are not well institutionalised.

Police authorities to some degree fit uneasily within the network since almost all other Concordat's signatories are either health policymakers and managers, or 
officials in local authorities. On top of the governance structure sits the Health and Wellbeing Board compromising high ranked officers at a strategic level. All the way down the next tiers, police representatives attend meetings and workshops to debate and agree better practices. These meetings are led by a senior manager from the Partnership Commission Unit (PCU) that embodies the four Clinical Trusts providing health services in the region. Initial policymaking efforts seemed very straightforward as other actors were keen to see the police take a lead in the discussion and potential execution of new practices that blended health and policing services. A senior PCU representative highlighted the latter situation.

If we are talking about urgent care, absolutely the police should be there because they play a very significant part.

Another health policymaker argued in the same line.

The police are often the first people to see somebody in crisis, so it makes sense that they actually consider how effective they are at being able to support that person.

Police participation in the Concordat came as well to put greater focus on discussing what role the police delivers today in public services. For instance, local authorities would press on the issue that police officers are moving away from a criminal justice perspective to a social care responsibility. The issue was highlighted as well by a senior manager in the Office of the Police and Crime Commissioner (PCC).

Vulnerability is massive for the police force, so I suppose the public would perceive that the police force's work is about finding criminals and detecting crime, but it's far larger than that, and wherever someone has a need or has a concern for someone and doesn't quite know how to address that, they will often call the police.

To some interviewees, this reflected on the police feeling of duty towards those in need. Another senior member of the PCC would argue in a similar way. 
Police are really risk-averse, so if they are presented with a problem with an individual that appears to be vulnerable, they feel that they have to resolve that issue, and they are risk-averse to walking away from that scenario.

Nevertheless, decentralisation and austerity came to play a big part. Because all related actors in the Concordat enjoyed so much discretion in their own services, the fact that budgets were being reduced, and some of its services were to disappear or be reformed, finding agreements on shared services was difficult. Early on those police officers participating in the various policy meetings called by the Concordat realised the difficulties of agreeing on policy priorities and moreover what role should the police take on. A high ranked police officer argued that many mental health crises should not fall strictly in the services provided by the police.

For somebody with a mental health issue, for example, the policing involvement should be really relatively limited, even when they have committed a crime. A medical intervention is a better intervention than a policing or criminal justice intervention

Table 1 sets out the most relevant issues that police officers evidenced when participating in the Concordat's governance structure.

\section{TABLE 1 ABOUT HERE}

Police accounts revealed that austerity was hindering an effective compromise on the nature and form of service provision and this was creating greater demand on an already struggling police force. Officers would often express frustration, anger, powerlessness and resignation with the referrals to the health service (see Martin and Thomas 2015). In North Yorkshire, police personnel argued that emergency departments are reluctant to assess people in crisis that do not meet criteria for admission, or if admitted, they are quickly discharged. Police would argue that they were left with dealing with a great amount of people not being attended by the services cut off from the health system. 
One response policing inspector in North Yorkshire Police struggled to understand why, first of all, people was contacting the police rather than the crisis services.

In the evenings and in the small hours, most often, people ring up saying "I am going to self-harm", and they ring from within their houses, they ring from in public, they are reported by members of the public for behaving erratically. I would say probably our greatest call for service is by people themselves ringing us telling us that they are in crisis.

The discussion over what role the police offer to communities is common across national forces. One chief inspector working on the mental health team in Norfolk Constabulary mentioned the following.

I think other agencies misunderstand what powers the police have. For example, the Trust cannot recruit at the minute, they have got massive vacancies, and they are in special measures. They have not got enough staff that are trained, so when something goes wrong, they tend to ring the police more than they did before. And then the police are not very happy because we see it as not our role.

One senior official in North Yorkshire's Office of the Police and Crime Commissioner noted the preoccupation among regional elected authorities in caring not only for police forces but also for the public when other services are failing.

You see police and crime commissioners across the board very keen to do what they can, firstly from the public's point of view but also from the police's point of view because we recognise it creates risk for the police, and we do not want our officers to be put in difficult situations that they are not trained or able to deal with which might then lead to a really bad outcome for somebody who is ill.

But as the interviewee from Norfolk Constabulary mentioned, police have only restricted statutory faculties to deal with the public in health crises. 
When we were talking about partnership working, understanding the other organization, it is really important. And I think, as the police, we are not particularly good at that. We expect other partners to understand us and we expect other partners to know that we have not got legislation to cover what they want us to do.

Polycentric governance is compromised when partnerships are not managed well. The introduction of new governance arrangements is complex, although what is more worrying, the risk of network governance not working at all is not as big as "leaving a troubling public problem unaddressed" (Emerson and Nabatchi 2015, 210).

\section{Second obstacle: Resistance within organizations opposed to novel forms of governance, more so in a context of austerity}

Besides its participation in the Concordat, North Yorkshire Police had begun an internal review process of what aspects were essential to improve when handling the issue of dealing with mental health related incidents (see Table 2). In part these weaknesses were in line with other forces being reviewed. In 2013, an independent commission reviewed the Metropolitan Police Service policing and health practices and found three areas of most concern: leadership, the capacity of frontline officers, and interagency working (ICMHP 2013). North Yorkshire police identified its own weaknesses. These were mostly in the identification, recording, response, referral and review of its mental health policing practices. Again, decentralisation and austerity have impacted on service delivery. North Yorkshire Police's attempts to overcome their lack of skills to identify and handle mental health incidents were costly and required extra resources that were not an item in the previous budgets. In addition, because the police forces in Britain are regional institutions, the lack of centralised common protocols or guidelines towards addressing mental health became an issue. Without statutory requirements but a need to deal with the issue, mental health demanded extra resources that each police constabulary had to find. Consequently, referral pathways to the health services can change abruptly according to geographic patterns that did not necessarily match those of the police constabularies. Both local authorities and health policymakers would nonetheless highlight the lack of tools that current police officers have to deal with mental health issues. Despite their annual training on various aspects of policing, police 
personnel not always have access to mental health specific instruction. A police inspector working in the district of Harrogate, in North Yorkshire, recalled his desire for more adequate preparation to deal with such cases.

There isn't a formal training programme, and with the time pressures that we are under, with the variety of things that we do, I don't know if we would ever get one through. It is almost through day-to-day improving practice, trying to keep an ear to the radio, I'll just call to my responding officers and say, "try it this way, use this power, tell the mental health person this". And it is just through practice really, it is improving practice we have got there.

\section{TABLE 2 ABOUT HERE}

With the retrenchment of services once given by the health sector, mental health related care has fallen increasingly within the remit of the police. Assistance from the police, for instance, is required to commit the patient to a hospital for continued psychiatric treatment. Such issues were discussed by a NHS crisis services manager.

The police are showing a much wider interest in the health status. Not only with street triage and urgent care but they're also interested in safer neighbourhoods for people with dementia, and safe places for people with learning disabilities. That feels healthy, because the community patch is the police. When you think about being safe in the community you think about the police.

Police officers in general desire greater cooperation with psychiatric care personnel and want to know more about mental illness and how to approach those with mental illness (Erdner and Piskator 2013). Mental illness training programs delivered to lawenforcement officers favours training using realistic "hands-on" scenarios (Krameddine and Silverstone 2014). However, creating empathy, communication skills, and the ability of officers to de-escalate situations takes time and expensive resources. A member from the voluntary sector argued that training for the police should be provided by those organizations with a greater expertise on mental health. 
I am aware that the police's main priority is the safety of the individual and community and I think it's about how we equip the police to be more aware, more understanding, more empathic to people with mental health problems whilst still enabling them to do their job.

Even though, the Home Office was committed to the Concordat and expected that its policy agenda would come from the regions, it did not consider that public services, most significantly the police forces, would have to re-think their policing practices and consequently come up with extra money to sort them out. More so, resistance inside organizations became difficult to overcome. In network governance regimes the permeation of sectorial boundaries does not come easy.

\section{Third obstacle: Unintended consequences and new demands created by expenditure cuts further stress local service delivery}

The embedding of police in the mental health system has considerable resource implications for the policy which are not accounted for by other agencies. Police interventions involving individuals with mental health illnesses can use up to $87 \%$ more resources than interventions involving the non-mentally ill users (Charette, Crocker, and Billette 2014). Experiences worldwide have proposed various frameworks relevant to policymakers across the public sector in order to draw the map for a collaborative mechanism between levels of policy. The key component identified has been the role of an integration coordinator: a person who is able to facilitate relationships and ensure effective information flows. North Yorkshire Police has followed such model piloting Street Triage teams where police officers attend incidents in conjunction with a nurse or paramedic who acts as a liaison to the health and crisis services. A member from the voluntary sector was keen in seeing clinical personnel working inside the bureaucracies of the police as the most recent Force Control Room Triage initiative aimed for.

You need specialist trained mental health workers to be part of the police force and not working in partnership with them but actually in the police force. 
However, having in house clinical personnel and the triage experiences are costly and a big part of the resources come straight from the police's pocket. This, despite that they are taking a wider role in services that should be provided as well, or at least financed in conjunction with the health sector. For health managers, however, the situation is different as they benefit from the spill over of services.

Street triage has a huge positive impact on one agency, the police. However, we also have secondary gain through inter-mental health services.

For a police mental health lead in Norfolk Constabulary, the inter-agency seems to have worked better when professionals share perspectives between policing and health.

I was a nurse for 10 years before I joined the police, so in terms of the health service, I am not a stranger to the health service, I speak the right language, and I understand the dynamic, so that makes me credible at both sides.

The triage initiatives were aimed at lowering the number of detainees under the Section 136 Mental Health Act 1983. Police staff try to avoid taking vulnerable adults and children into the custody suite and have arranged a Section 136 Suite with qualified personnel in a clinical environment. However, when other services are not available to support them, custody seems the only option. As it happens in other constabularies in the country, the lack of shared information between the police and other agencies from the healthcare services "has meant that police officers often respond to vulnerable individuals, and make decisions on whether to arrest, with little background knowledge of the individual's circumstances" (HMIC 2015, 18). For instance, from January to September 2014, out of the 255 people detained in North Yorkshire under the mental health act 57 per cent were taken to "places of safety", 13 per cent to accident and emergency units, and 30 per cent went into custody. Even though there have been resources spent in places of safety in two regional hospitals ( $£ 400,000$ in York’s Bootham Park Hospital and $£ 250,000$ in Scarborough Cross Lane Hospital), police get referrals refused mostly when detainees are considered too violent, and sometimes when units are full (Liptrot 2014). The different triage initiatives in North Yorkshire have been intended to resolve this situation but budgetary constraints create uncertainty over whether the services will be retained in the long term and mean that the form of 
integrated services is effectively a temporary measure dependent on ad hoc funding (see Table 3). A review by 21 police forces using Section 136 found that " 264 cases involved the police feeling obliged to keep someone safe by holding them in custody beyond the period allowed by custody law because of delays in finding a hospital bed" (NPCC 2017a). Data published in October 2017 shows that people kept in police cells having been detained under Section 136 halved in relation to the previous year. Still, in view of the forces, this has come "as the police service is dealing with a growing number of incidents related to mental health" (NPCC 2017b).

\section{TABLE 3 ABOUT HERE}

The interagency policymaking amongst police officers and other crisis services has resulted in positive and negative outcomes for local governance. The police's enhanced awareness of how other local services operate has decompressed the burden of their services. As well, initiatives like the Street Triage have diverted people from going to crisis services, emergency departments, or inpatient hospitals. However, local network governance has been challenged by the disadvantage of certain actors in relation to preestablished policy networks. Over the last decade, the NHS community has achieved greater inter-agency collaboration between practitioners and managers. However, these linkages have not always translated into working with other actors such as the police, or the local authorities in councils and districts. Also, these relationships do not always permeate at the institutional level, thus when police officers move jobs, knowledge and commitment is forgotten. A mental health lead officer from Nottinghamshire Police emphasised the importance of personal relationships

I have really good relationships with the managers from the crisis teams, from the accident and emergency department, so it is quite easy for me to get in the door if we have incidents which cause issues, and for us to have a meeting and look to open those boundaries.

A police officer leading with the mental health portfolio in Hampshire Police argued in the same vein. 
One of the advantages of street triage as Leicestershire put it a few years ago in a corny way it's the vehicle for change, street triage is a physical vehicle but also a metaphorical vehicle for new relationships. And especially on the Isle of Wight where we have got one police, one CCG, one NHS, one ambulance, and one ED, very simple. But actually, even if you have a really complex political structure, it fundamentally comes down to face-to-face, compassionate relational leadership, and that's the answer to the question.

In other police forces, organizational characteristics, accountability structures and resource limitations still hinder the integrated front-line delivery of mental health. One senior police officer in North Yorkshire Police was able to identify at least two drivers of such an issue.

We don't have that strategic buy-in, we are not using the power of commissioned services or commissioned funds jointly so the commissioner in North Yorkshire has quite a significant amount of money to put into commissioned funds. The health service has a lot more money to put into commissioned funds. If those were pulled and targeted, then I think that could be more effective. Tactically, we are not sufficiently joined up, we should be closer aligned.

Another police officer in Great Manchester Police complained about agencies depending on services that police should not be covering.

We had issues with G4S who were at the courts and said, "it's not our contract to convey people from court to hospital, we convey people from court to prison". Police officers who happened to be at court were being asked to convey people to the metal health unit. Again, that shouldn't be our job either. This is the issue, we are reliant on our partners but when one service can't meet what they should be meeting, it has a negative impact on us all.

The de-centralised and pluralistic decision-making in sectors such as health, community services, and the voluntary sector has clashed with the more hierarchic and centralised approaches of public actors such as the police and other emergency services. 
A typical result of the latter situation is that actors end up agreeing policy programmes that once in its delivery are very hard to pull together. Police officers feel that other agencies do not commit to comprehensive policies but in the context of austerity rely on police services as a fall back. One police inspector from North Yorkshire Police argued the following.

What we find in practice is we are called in the very first instance and it feels like it's just given to us then to sort the issue out. And when I make those challenges to say you know these actions should have been carried out in the first instance and they still need to be carried out by you before we step in, the health side will say we have nobody to do it. And they haven't, that's the thing, it's not being done through obstinacy or laziness or whatever, they simply haven't got the people to fulfil the requirements of their own policy.

Police forces across the UK commit time and energy to pursue multiple goals and rarely avoid calls from another services. However, unintended consequences and new demands created by expenditure cuts further stress local service delivery when network collaborations for agencies to participate in policies that demand services beyond their responsibilities exposing them to uncompensated risks.

\section{Conclusion: Networks, austerity, and policy delivery}

This article's findings illustrate the difficulty of using austerity as a driver of political reform in the context of polycentric and networked governance. Tighter budgets have forced agencies to work together to find ways of improving service delivery. The joint working is complex, multi-layered and to a degree overlapping. As we have seen, the devolution of policymaking, the reduction of central bureaucracies, and the abolition of top-down accountability means that local governance is now conducted more seriously through the steering of new regional boards, quasi-governmental agencies, and a range of fora for policy programmes that agree locally what needs to be done in the front line of services. From our case study we point out the fact that some service integration is on its way does not mean that divergent implementation can still happen as an unintended outcome. Cross-agency working need to overcome issues of 
individualisation in order to avoid seen fragmented governance as a suggestion of failure.

Second, we argue that the paradox of austerity is that whilst the pressures of budget cuts are intended to create pressure for better joined up government, these pressures are mediated by the governance structures (Hood and Dixon 2013; Cepiku, Mussari, and Giordano 2016). The case of North Yorkshire's police has illustrated both the positive and negative impacts of austerity driven decentralisation. There are now structures in place and a strong willingness to improve joint working. Police coallocation in "community safety hubs" alongside council staff has merged resources, legal powers, and expertise to deliver, in a single frontline team, solutions to anti-social behaviours and vulnerability (North Yorkshire Police 2015). Community safety hubs have become essential as the demand for better cross-service assessment of anti-social behaviour has increased upon local authorities. However, police participation in these multi-actor forums brings unintended consequences for the good and the bad of law enforcement agencies (see Grace and O'Malley 2014). On the one hand, police agencies are encouraged to coordinate short term responses to complex cases of community safety. However, it has been highlighted that the decision-makers inside the force might lose accountability, communication, and the steering of their own resources, as local hubs get more intricate, independent, and institutionalised. That said, decisions are often made together and there is a recognition across different agencies that solutions can only come with shared working. Through street triage and changes in operations, for instance, medical staff are often working with police personnel. However, there continue to be significant problems. There is a lack of a single authority able to make decisions and consequently, each decision on partnership is contingent, ad hoc and usually time limited. Without an overall authority each agency makes autonomous decisions which undermine attempts at partnership policies. Budgets are not shared and so there are conflicts over who pays for which services and many of the joint working activities are paid for out of temporary sources of funding. There are still problems over data sharing - even within organizations with for instance the police having different systems for recording incidents. There are also significant overlaps of service provision spatially and a lack of clarity in terms of who has responsibility where. Ultimately, attempts to reconfigure services shift patterns of demand without shifting budgets which results in agencies attempt to protect their services rather than creating a joined-up approach to mental health. 
Third, the research has brought to light that policy actors tend to ring-fence their budgets and local collaborations are being restricted to specific and circumstantial sets of policies. Policy actors in the regions should expand their budget and organizational boundaries to create more intertwined services responses and financing alternatives for when new cuts come. In a sense, to cope with the new scenario of local governance under austerity and financial uncertainty, public service institutions should arrange for rethinking the old and proven ways of delivering services with the new untested formulas (Lowndes and McCaughie 2013). Consequently, what we see is network governance that is inchoate rather than the sort of coordinated approach assumed by much of the literature (see a thorough discussion in Klijn and Koppenjan 2016). The lack of overarching authority makes both policy reform and delivery difficult and raises important questions about how services are organized within localities. Hence, there is a problem that lines of responsibility and accountability are blurred. There is no simple mechanism of decision making and budgets are not shared. This leads to a problem that it is individuals and not institutions that are working together and the policy depended on negotiations between individuals rather that a clear institutional framework. In conclusion, the case study of the North Yorkshire Police in the UK and the provision of mental health services has enlightened our understanding of current governance manifestations. Specialised public services competencies have fallen into bigger and cross-cutting issues of public administration that the current model of governmental steering seems to neglect. 
TABLE 1 List of issues identified by police representatives when participating in the Mental Health Crisis Care Concordat for York and North Yorkshire

\begin{tabular}{|c|c|}
\hline Strategy Board & $\begin{array}{l}\text { - Not sufficient joined up strategic partnerships. } \\
\text { - Better relations with local authority representatives than } \\
\text { with those from the health sector. } \\
\text { - Need to develop protocols with partners to hand over not } \\
\text { police-related mental health issues. }\end{array}$ \\
\hline $\begin{array}{l}\text { Implementation } \\
\text { Group }\end{array}$ & $\begin{array}{l}\text { - A unitary police force working with various local } \\
\text { government structures is a challenge. } \\
\text { - The importance between policing and mental health } \\
\text { practices is only recently becoming apparent. }\end{array}$ \\
\hline $\begin{array}{l}\text { Task and Finish } \\
\text { Group }\end{array}$ & $\begin{array}{l}\text { - There is a need to incorporate to other police officers the } \\
\text { expertise gained by frontline staff working with partners. } \\
\text { - Incident responses should be through quick actions based } \\
\text { on intelligence sharing agreements. } \\
\text { - A police-led style of meetings should be avoided and } \\
\text { encouraged a partners-oriented type of discussion. }\end{array}$ \\
\hline $\begin{array}{l}\text { Reference } \\
\text { Group }\end{array}$ & $\begin{array}{l}\text { - Scarce prevention strategies for mental health crises and the } \\
\text { constant referral of users from one service to another has } \\
\text { hindered partnerships' work. }\end{array}$ \\
\hline
\end{tabular}


TABLE 2 Pressing concerns to the Police when dealing with mental health issues

\begin{tabular}{llll}
\hline Issue & $\begin{array}{l}\text { Proposed ways to } \\
\text { overcome them }\end{array}$ & $\begin{array}{l}\text { Extra } \\
\text { resources } \\
\text { needed }\end{array}$ & $\begin{array}{l}\text { Obstacles for } \\
\text { institutional } \\
\text { embrace of } \\
\text { desired practices }\end{array}$ \\
\hline $\begin{array}{l}\text { Identification } \\
\begin{array}{l}\text { Identification of a mental } \\
\text { health component has not } \\
\text { been a mainstream issue for } \\
\text { policing. }\end{array}\end{array} \quad \begin{array}{l}\text { Training to police } \\
\text { personnel. }\end{array}$ & $\begin{array}{l}\text { Financing } \\
\text { training and } \\
\text { taking } \\
\text { personnel off } \\
\text { the street. }\end{array}$ & $\begin{array}{l}\text { Preparation and } \\
\text { delivery of } \\
\text { training is time } \\
\text { demanding and } \\
\text { consuming. }\end{array}$ \\
\hline
\end{tabular}

\section{Record}

Absence of a recording standard has caused underreporting of incidents.

Incomplete case recording of people/incidents (poor recording in-situ or though the control room).

\section{Response}

Poor knowledge of policing/societal interventions to mental health incidents. Discretion versus doctrine when applying problemsolving strategies.

Introduction of a
flagging system to
mark incidents or
users as having
potential mental health
components.

Extra work (time and resources) for personnel.
Creation of co-located teams (hubs) for early prevention and intervention.

Street and Force Control Room Triage pilots.

Alliance with health, local authorities and voluntary sector for referrals.

Creation of mental health reports to be submitted for corporate performance and scrutiny.
Financing the allocation of police personnel per local hub.

Financing the pilots (see table 5).

More resources needed as demand for referrals grows.

Extra work
(time and
resources)
demanded
from
personnel.

Hubs have grown without central steering.

Short pilots have not contributed to personnel absorption of triage practices.

Front line staff's awareness of referral pathways is limited.

\section{Review}

Police's interest in creating data-based reports for review of practices is still limited. 
TABLE 3 Recent police practices to improve responses to mental health related incidents

\begin{tabular}{|c|c|c|c|c|c|}
\hline $\begin{array}{l}\text { Policy } \\
\text { plan }\end{array}$ & Location & $\begin{array}{l}\text { Institutions } \\
\text { involved in its } \\
\text { delivery }\end{array}$ & Costs & Funded by & Results \\
\hline $\begin{array}{l}\text { Street } \\
\text { Triage } \\
\text { Pilot }\end{array}$ & $\begin{array}{l}\text { Scarbo- } \\
\text { rough, } \\
\text { Whitby, } \\
\text { Ryedale }\end{array}$ & $\begin{array}{l}\text { Police, Office of the } \\
\text { Police and Crime } \\
\text { Commissioner, NHS } \\
\text { TEWVs Foundation } \\
\text { Trust }\end{array}$ & $£ 200,000$ & $\begin{array}{l}\text { First year: } \\
\text { Department of } \\
\text { Health } \\
\text { Second year and } \\
\text { onwards: Police; } \\
\text { Office of the } \\
\text { Police and } \\
\text { Crime } \\
\text { Commissioner; } \\
\text { Scarborough and } \\
\text { Ryedale CCG }\end{array}$ & $\begin{array}{l}\text { Program } \\
\text { started in } \\
\text { March 2014 } \\
\text { and renews } \\
\text { every 12 } \\
\text { months }\end{array}$ \\
\hline $\begin{array}{l}\text { Street } \\
\text { Triage } \\
\text { Pilot }\end{array}$ & York & $\begin{array}{l}\text { Police, Office of the } \\
\text { Police and Crime } \\
\text { Commissioner, NHS } \\
\text { TEWVs Foundation } \\
\text { Trust }\end{array}$ & $£ 200,000$ & $\begin{array}{l}\text { Vale of York } \\
\text { CCG; City of } \\
\text { York Council } \\
\text { and North } \\
\text { Yorkshire } \\
\text { County Council }\end{array}$ & $\begin{array}{l}\text { Program } \\
\text { started in } \\
\text { October } 2014 \\
\text { and renews } \\
\text { every } 12 \\
\text { months }\end{array}$ \\
\hline $\begin{array}{l}\text { Force } \\
\text { Control } \\
\text { Room } \\
\text { Triage } \\
\text { Pilot }\end{array}$ & $\begin{array}{l}\text { Based in } \\
\text { York but } \\
\text { operative } \\
\text { county- } \\
\text { wide }\end{array}$ & $\begin{array}{l}\text { Police; Office of the } \\
\text { Police and Crime } \\
\text { Commissioner; NHS } \\
\text { TEWVs Foundation } \\
\text { Trust }\end{array}$ & $£ 174,000$ & $\begin{array}{l}\text { Police; Office of } \\
\text { the Police and } \\
\text { Commissioner }\end{array}$ & $\begin{array}{l}\text { Program } \\
\text { funded for } 15 \\
\text { months } \\
\text { starting } \\
\text { January } 2016\end{array}$ \\
\hline $\begin{array}{l}\text { Path- } \\
\text { ways } \\
\text { Project }\end{array}$ & York & $\begin{array}{l}\text { Together for Mental } \\
\text { Wellbeing; Police } \\
\text { and other referring } \\
\text { agencies. }\end{array}$ & $£ 287,000$ & $\begin{array}{l}\text { Vale of York } \\
\text { CCG; Lankelly } \\
\text { Chase } \\
\text { Foundation; } \\
\text { NHS England }\end{array}$ & $\begin{array}{l}\text { Program } \\
\text { funded for } 24 \\
\text { months } \\
\text { starting } \\
\text { April } 2015\end{array}$ \\
\hline
\end{tabular}




\section{References}

Adebowale, V. 2013. "Independent Commission on Mental Health and Policing Report.” http://news.bbc.co.uk/1/shared/bsp/hi/pdfs/10_05_13_report.pdf

Bevir, M. 2011. "Governance as Theory, Practice and Dilemma." In The SAGE Handbook of Governance, edited by M. Bevir, 1-16. London: Sage.

Blyth, M. 2013. Austerity: The history of a Dangerous Idea. Oxford: Oxford University Press.

Cepiku, D., R. Mussari, and F. Giordano. 2016. Local Governments Managing Austerity: Approaches, Determinants and Impact. Public Administration 94 (1): 223 243.

Charette, Y., A.G. Crocker and I. Billette. 2014. "Police Encounters Involving Citizens with Mental Illness: Use of Resources and Outcomes." Psychiatric Services 65 (4): 511-516.

Crosby, B.C., and J.M. Bryson. 2010. "Integrative Leadership and the Creation and Maintenance of Cross-Sector collaborations.” The Leadership Quarterly 21 (2): 21130.

Curristine, T., Z. Lonti, and I. Joumard. 2007. "Improving Public Sector Efficiency: Challenges and Opportunities.” OECD Journal on Budgeting 7(10): 1-41.

Dare, M. and K. A. Daniell. 2017. "Australian Water Governance in the Global Context: Understanding the Benefits of Localism." Policy Studies 38 (5): 462-481.

Davies, J. 2011. Challenging Governance Theory. Bristol: The Policy Press.

Emerson, K., and T. Nabatchi. 2015. Collaborative Governance Regimes.

Washington, DC: Georgetown University Press. 
Erdner, A., and R. Piskator. 2013. "Police Experiences of Committing People with Mental Illness to a Hospital." Issues in Mental Health Nursing 34 (7): 550-555.

Ericson, R.V. 1994. "The Division of Expert Knowledge in Policing and Security." The British Journal of Sociology 45 (2): 149-175.

Fleming, J., and R.A.W. Rhodes. 2018. Can Experience Be Evidence? Craft Knowledge and Evidence-Based Policing. Policy \& Politics 46 (1): 3-26.

Grace, S., and L. O’Malley. 2014. "A Brief Evaluation of the York ASB Hub.” http://democracy.york.gov.uk/documents/s96393/ASB\%20Hub\%20-\%20Update\%20$\% 20$ Annex\%201.pdf.

HM Inspectorate of Constabulary. 2015. "The Welfare of Vulnerable People in Custody". http://www.justiceinspectorates.gov.uk/hmic.

HM Government. 2011. "No Health Without Mental Health: A Cross-Government Mental Health Outcomes Strategy for People of All Ages." https://www.gov.uk/government/uploads/system/uploads/attachment_data/file/213761 /dh_124058.pdf.

Hood, C., and R. Dixon. 2013. "A Model of Cost-Cutting in Government? The Great Management Revolution in UK Central Government Reconsidered.” Public Administration 91 (1): 114-34.

Hupe, P., and A. Buffat. 2014. "A Public Service Gap: Capturing Contexts in A Comparative Approach of Street-Level Bureaucracy." Public Management Review 16 (4): 548-569.

Independent Commission on Mental Health and Policing (ICMHP). 2013. "Report". http://news.bbc.co.uk/1/shared/bsp/hi/pdfs/10_05_13_report.pdf.

Institute for Fiscal Studies (IFS). 2015. "This Government Has Produce Big Spending Cuts.” http://election2015.ifs.org.uk/public-spending. 
Isett, K. R., I. A. Mergel, K. LeRoux, P. A. Mischen, and R. K. Rethemeyer. 2011.

"Networks in Public Administration Scholarship: Understanding Where We Are and Where We Need to Go." Journal of Public Administration and Research Theory 21(1): 157-73.

Krameddine, Y. I., and P. H. Silverstone. 2014. "How to Improve Interactions Between Police And The Mentally Ill." Frontiers in Psychiatry 5 (186): 1-5.

Klijn, E. H., and J. F. M. Koppenjan. 2016. Governance Networks in the Public Sector. London: Routledge.

Lamb, H.R., L. E.Weinberger, and W. D. de Cuir Jr. 2002. "The Police and Mental Health.” Psychiatric Services 53 (10): 1266-1271.

Lidén, G., J. Nyhlén, and S. Nyhlén. 2015. "Forced Cooperation from above: The Case of Sweden's Establishment Reform.” Policy Studies 36 (5): 468-486.

Lipsky, M. 1980. Street-level bureaucracy: Dilemmas of the Individual in Public Services. New York: Russell Sage Foundation.

Liptrot, K. 2014. "People Detained Under Mental Health Act in North Yorkshire Still Held in Police Cells.” The Press, 27 November. http://www.yorkpress.co.uk/ News/11629254.Fears_over_custody_dangers_for_people_detained_under_mental_h ealth_act/.

Liu, Y., Y. Li, B. Xi, and J. Koppenjan. 2016. “A Governance Network Perspective On Environmental Conflicts in China: Findings from The Dalian Paraxylene Conflict." Policy Studies 37 (4): 314-331.

Local Government Association. 2013. "Future Funding Outlook for Councils 2010/11 to 2019/2020.” http://www.local.gov.uk_c/document_library/get_file? Uuid=b9880109-a1bc-4c9b-84d4-0ec5426ccd26\&groupId=10180. 
Lowndes, V., and K. McCaughie. 2013. Weathering The Perfect Storm? Austerity and Institutional Resilience In Local Government. Policy \& Politics 41 (4): 533-549.

McGinnis, M. D., \& E. Ostrom. 2011. "Reflections On Vincent Ostrom, Public Administration, And Polycentricity." Public Administration Review 72 (1): 15-25.

Martin, T., and S. Thomas. 2015. "Police Officers' Views Of Their Encounters With People With Personality Disorder.” Journal of Psychiatric and Mental Health Nursing, 22 (2): 125-132.

Matthews, F. 2012. “Governance and State Capacity.” In The Oxford Handbook of Governance, edited by D. Levi-Faur, 281-293. Oxford: Oxford University Press.

National Police Chiefs' Council (NPCC). 2017a. "Thousands Of People Suffering Mental Health Issues May Be Unlawfully Held By Police Due To Delays Accessing Appropriate Inpatient Beds.” https://news.npcc.police.uk/releases/thousands-ofpeople-suffering-mental-health-issues-may-be-unlawfully-held-by-police-due-to-lackof-available-hospital-beds.

National Police Chiefs' Council (NPCC). 2017b. “Fewer People With Mental Health Problems Kept In Cells - But Demand On Police Continues To Grow." https://news.npcc.police.uk/releases/fewer-people-with-mental-health-problems-keptin-cells-but-demand-on-police-continues-to-grow.

Normore, A. H., B. Ellis, and D. H. Bone. 2015. "The Defragmentation of Mental Health Services, Police, and the Homeless." Policing: A Journal of Policy and Practice 10 (2): 134-142.

North Yorkshire Police. 2015. "York-based Community Safety Hub Shortlisted for Finance for the Future Awards 2015." http://www.northyorkshire. police.uk/cshubaward. 
Organization for Economic Co-operation and Development (OECD). 2013.

“Government at a Glance." http://www.oecd-ilibrary.org/governance/government-ata-glance-2013/citizen-satisfaction-with-public-services_gov_glance-2013-56-en.

Osborne, D., and T. Gaebler. 1994. Reinventing Government: How The

Entrepreneurial Spirit Is Transforming the Public Sector. New York: Plume.

Ostrom, E. 2010. "Beyond Markets and States: Polycentric Governance of Complex Economic Systems.” American Economic Review 100 (3): 641-672.

PrivewaterhouseCooper. 2007. "Public Sector Research Centre: The Road Ahead for Public Service Delivery Delivering On the Customer Promise.” https://www.pwc.com/gx/en/psrc/pdf/the_road_ahead_for_public_service_delivery.pd $\mathrm{f}$

Provan, K.G., and P. Kenis. 2008. "Modes of Network Governance: Structure, Management, And Effectiveness." Journal of Public Administration Research and Theory 18 (2): 229-252.

Rhodes, R. A. W. 2012. "Waves of Governance." In The Oxford Handbook of Governance, edited by D. Levi-Faur, 33-48. Oxford: Oxford University Press. Smith, M., D. Richards, A. Geddes, and H. Mathers. 2011. "Analysing Policy Delivery in The United Kingdom: The Case of Street Crime and Anti-Social Behaviour." Public Administration 89 (3): 975-1000.

Smith, M. 2014. "Globalisation and The Resilience of Social Democracy: Reassessing New Labour's Political Economy." British Journal of Politics and International Relations 16 (4): 597-623.

Stoker, G. 2011. "Was Local Governance Such a Good Idea? A Global Comparative Perspective". Public Administration 89 (1): 15-31. 